\title{
Landscape Dynamics in Mediterranean Coastal Areas: Castelló de la Plana in the Last Hundred Years
}

\begin{abstract}
The littoral areas of the Mediterranean coastline have undergone a significant transformation due to their historical and intense human occupation. The result has been an evolution of different cultural landscape configurations, ranging from those with a marked agrarian character to artificial ones derived from the process of urbanisation and metropolitan growth. The objective of this paper is to define a model to characterise landscape types and units that explains the landscape dynamics (1910-2015) in Mediterranean coastal spaces at local scale, taking as study area the municipality and surroundings of Castelló de la Plana, in Spain. The aim is to identify the way in which society has appropriated and occupied this space. This research seeks to analyse landscape metrics that link dynamics in both space and time to provide a comprehensive image of landscape dynamics. The methodological procedure is based on the diachronic study of the landscape to discern a pattern of change in the cultural landscape over time and space that allows us to explain the current situation of the landscape and its relationship with urbanisation and urban planning.
\end{abstract}

\section{Keywords:}

Landscape Dynamics, Landscape Metrics, Cultural Landscape, Urbanisation

\author{
Rafael Belda-Carrasco ${ }^{1,2 *}$, Emilio \\ Iranzo-García ${ }^{1}$, Juan A. Pascual- \\ Aguilar ${ }^{2,3}$. \\ ${ }^{1)}$ Universitat de València, \\ Department of Geography, Cátedra \\ de Participación Ciudadana y \\ Paisajes Valencianos, Valencia, Spain \\ 2) Centro para el Conocimiento del \\ Paisaje, Area of Spatial Analysis, \\ Matet, Spain \\ 3) IMDEA Water Inst., Geomatics \\ Laboratory, Alcalá de Henares, Spain \\ *Corresponding author: Rafael \\ Belda-Carrasco, Universitat de \\ València, Department of Geography, \\ Cátedra de Participación Ciudadana \\ y Paisajes Valencianos, Avd. Blasco \\ Ibáñez 28; 46010 Valencia, Spain. \\ Email: rabelca@alumni.uv.es
}




\section{Introduction}

The peri-urban areas of the western Mediterranean coastal strip have undergone a major transformation caused by an historical and intense human occupation, with processes such as urbanisation, infrastructure development and land abandonment (García-Martín \& Ros-Sempere 2016; Smiraglia et al. 2015). There has been an increase in the number of inhabitants residing in the coastal areas and a progressive change of economic activities from the primary to the tertiary sector. The pressure has become even more acute due to tourism and the consequential rise in population and the vital service infrastructures required (Plieninger et al. 2016). The result has been a transformation of the landscape, expressed in different cultural landscape configurations over time (Marcucci 2000). Such transformations are deemed cultural, as they are a consequence of the interaction between the natural environment and the society inhabiting it in each historical period (Tieskens et al. 2017). Thus, the present territorial configuration is a combination that ranges from landscapes with a marked agrarian character (linked to the historical weight of the primary sector) to the recent urban and peri-urban process derived from urbanisation, metropolitan growth and outsourcing of economy.

The study of landscapes should not be separated from the historical spatial structures and the cultural processes that sustain them (Antrop 2005; GómezZotano et al. 2018; Kohler et al. 2015; Stephenson 2008). This historical and long-term landscape evolution explicates the common paths and turning points in landscape patterns (Bürgi et al. 2015; Smiraglia et al. 2015).In this way, when analysing the landscape and its historical dimension, we can promote sustainable development models that integrate social, economic and environmental factors in space and time (Antrop 1997; Agnoletti 2014).

The aim of this paper is to develop a methodology and geographical techniques to characterise and analyse the evolution of the landscapes in peri-urban areas of the western Mediterranean coast. Taking as our study area the municipality of Castelló de la
Plana, we will make explicit the driving elements in the evolution of the landscape, scaled in space and time. The purpose is to identify and understand the way in which society has appropriated and occupied this space, generating new landscape dynamics. This model is based in part of the landscape taxonomic pyramid (LTP) in the local spatial scale (Gómez-Zotano et al. 2018).The methodological approach developed qualifies and quantifies the transformation of landscapes, considering their historical dimension (evolution over space and time) and the identification of different cultural landscapes in each of the historical time series studied. This research is the basis for carrying out a qualitative analysis of change processes in each time series, as well as for generating a model that will allow for future transformation trends.

The study area corresponds to the municipality of Castelló de la Plana and its immediate surroundings, 20,500 ha in the Mediterranean coastal area of Spain (Figure 1). Its delimitation is not merely administrative, but has rather been extended beyond the limits of the municipality following the inclusion of complete landscape structures incorporating the municipal area, taking into consideration topography and viewshed landscape properties (Benevolo 1994).

\section{Materials and methods}

The methodological procedure is based on the diachronicstudy of the culturallandscape. Thelimiting factor of this method is the lack of documentation available (cartography, orthophotography or aerial and oblique photography, among others) and a deficit of homogeneity over time (Ode et al. 2010). The available data has been processed through geographic information systems (GIS) and a type of geospatial modelling LUCC (land use / cover change), although landscape types remain the base information. Landscape types set the criteria to mark and select the different stages of analysis in order to ascertain cultural landscape dynamics over time and space. This allows us to explain its current situation 


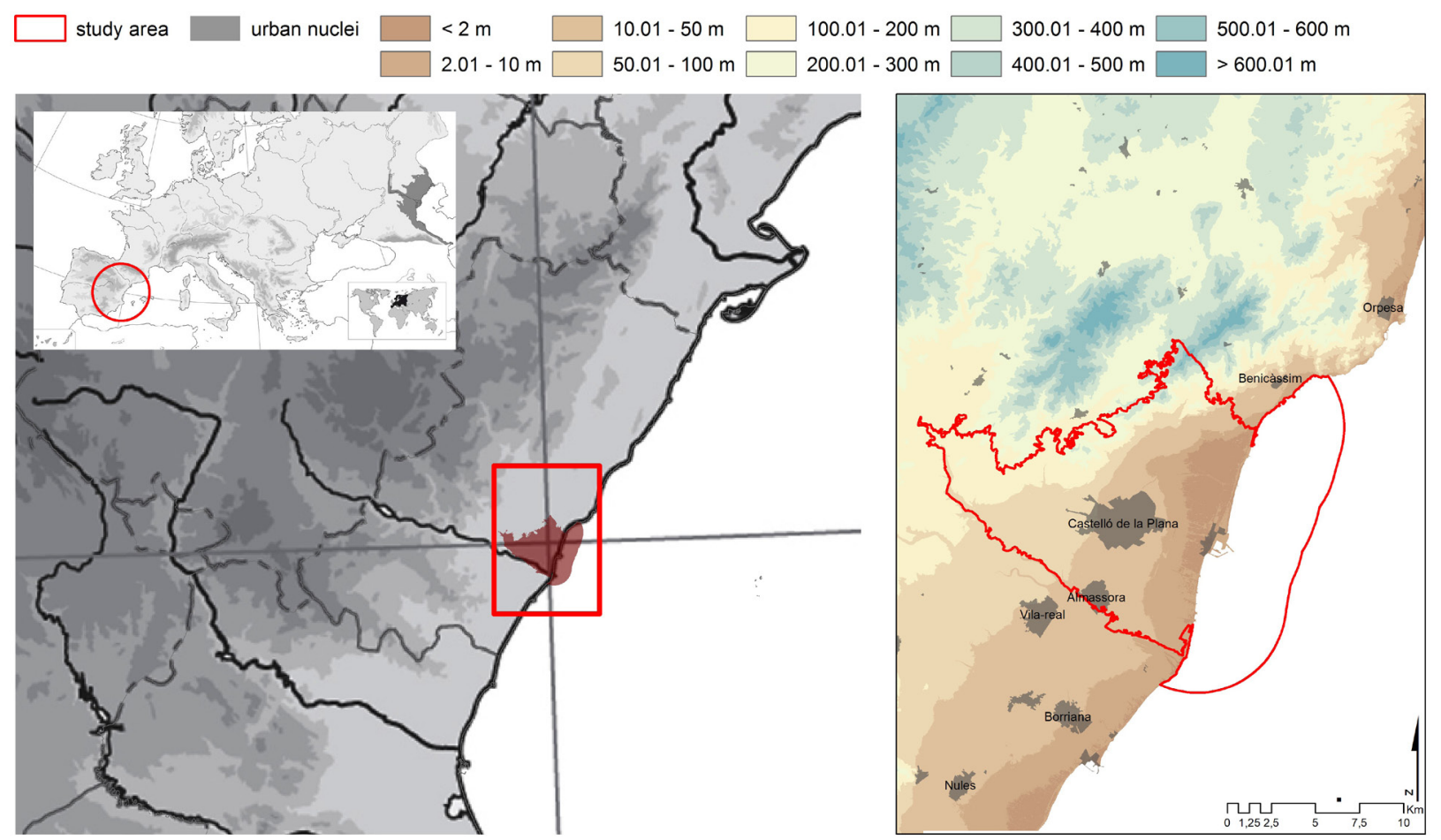

Figure 1: Situation map and location of the study area, Castelló de la Plana, Spain.

and its relationship with the city and, at the same time, it will help to improve decision-making for territorial (Palang et al. 2011) and urban planning.

\subsection{Methodology}

This landscape approach considers land cover, topography, lithology and biogeography as base information to determine landscape structures, based on the territorial structure determined by Gómez-Zotano et al. (2018) applied to local scale: type T4 of LTP. In this way, with the initial data and through the concept of landscape type, understood to be the classification of individual landscapes with distinct attributes (Wascher 2005), characterisation of the landscapes is initiated (Lang et al. 2008). We advance in this characterisation by adding historical texts and photographs to obtain the different types of landscape in each time series, which serves as the basis for carrying out the fieldwork. Thus, following the concept of land units as the delimitation of continuous and homogeneous landscape types sectors (Zonneveld 1989; Velázquez \& Bocco 2001) belonging to the characterised landscape types, landscape units are obtained homogeneously. These landscape units can be compared in each time series, thereby coming up with models and exchange rates corresponding to each landscape type (Antrop 2000).

The diachronic study of the cultural landscape is carried out, using the land cover polygons of Corine Land Cover as a base layer for the delimitation of landscape types for 2012 (Carvalho-Ribeiro et al., 2013), together with a previously calculated physiographic model (altitudes, slope gradients and slope aspects) (Aguilo et al. 1992; López et al. 2016), lithology and data on bioclimatic zones and biogeography (Costa Talens 1999; Rivas-Martínez et al. 2014). With this information, individual landscapes have been classified by their attributes to obtain landscape types representing a six-time series. These situations include the interpretation of orthophotography (2015 and 1997), aerial photographs (1977 and 1956) and historical cartography (planimetric maps for the years 1940 and 1910). With these types, we proceed to incorporate the historical information (texts and oblique photography), along with the execution of the current fieldwork, to obtain landscape units (Zonneveld 1989; Velázquez \& Bocco 2001) (Figure 2). 


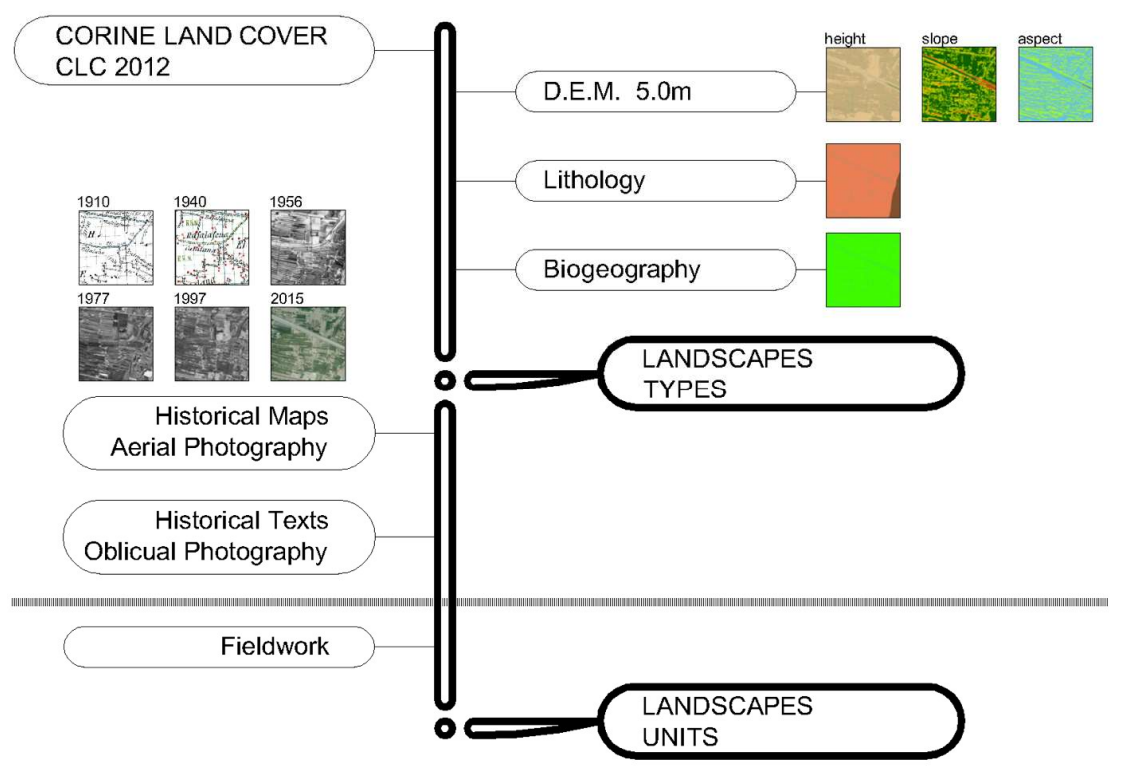

Figure 2: Outline global methodology.

\subsubsection{Stages of the methodological procedure}

This procedure sets out from a holistic landscape hypothesis (Antrop 2000), with an integrated vision of the elements that shape the landscape. The necessary data are obtained in order to arrange the materials that allow the passage from land cover of Corine Land Cover of 2012 to landscape types and finally to landscape units for each one of the time series. The information is pre-processed so as to perform photointerpretation of the different stages and gather a uniform time series that enables us to analyse the geo-history of the landscape (Antrop 2005).

Analysis of specific documentation (including reports; and statistical and graphic documentation) is carried out, when available, to determine the territorial environment organised by historical states that can guide the evolution and change of the landscape over time. Through fieldwork, the correlation between the compiled and processed documentation and the current landscape in the study area is checked. For this purpose, itineraries are made, pre-planned and supported with the data and notes obtained from the previously analysed documentation.
The data used to indicate the landscape types and landscape units are:

- Morphology: cartography and information of altitudes, slope gradients, slope aspects and hydrology (channels), obtained from the National Geographic Information Centre CNIG Geographical Download Centre (CNIG, 2017) and from Infraestructura Valenciana de Dades Espacials (Institut Cartogràfic Valencià 2017).

- Lithology: geological and lithological cartography and information, obtained from the Geoscientific Information Catalogue (Instituto Geológico y Minero de España 2017).

- Biotic: vegetation coverage (natural and agricultural), obtained from the Land Monitoring Service (Copernicus, 2017), bioclimatic zones of the Valencian area (Costa Talens 1999) and biogeographic units (Rivas-Martínez et al. 2014).

- Human: cartography and statistical data on population, settlements, typology of buildings and infrastructures (irrigation systems, communications networks, and facilities), obtained from the Land Monitoring Service (Copernicus, 2017) and statistical data with geographic properties sourced from the National Institute of Statistics (INE) database (INE 2008). 
- Protection: soils, landscapes, cultural and natural protected areas, obtained from Estructura Valenciana de Dades Espacials (Valencian Spatial Data Infrastructure) (Institut Cartogràfic Valencià 2017).

\subsection{Production and manipulation of base information}

This phase starts from the base information of the digital terrain model (DTM) with a definition of 5 $\mathrm{m}$ to perform the calculation and parameterisation of the physiographic model (Table 1). All the parameterisations (Aguilo et al. 1992; López et al. 2016) have been modified to adapt the externalities of the peri-urban areas of the western Mediterranean coastal strip specifically for the study area environment (Sanjaume Saumell 1985) and in this way, suitably incorporate the land uptakes from the grounding of the coastal lagoons and marshes.

Table 1: Parameterisation according to the digital terrain model.

\begin{tabular}{ll}
\hline Morphology & Parameterisation \\
\hline Altitude & $<1 \mathrm{~m}, 2 \mathrm{~m}, 10 \mathrm{~m}, 20 \mathrm{~m}, 50 \mathrm{~m}, 100 \mathrm{~m}$, \\
& $200 \mathrm{~m}, 300 \mathrm{~m}, 400 \mathrm{~m}, 500 \mathrm{~m},>500 \mathrm{~m}$ \\
\hline Slope gradient & $<1 \%, 3 \%, 6 \%, 10 \%, 20 \%,>20 \%$ \\
\hline Slope aspect & $0 \circ, 135 \div, 225 \circ, 360 \%$ \\
\hline
\end{tabular}

For the physiographic model, the hydrographic network (rivers, ravines and irrigation network) was taken into account (Obiol Menero \& Soriano Martí 2009), as well as lithology, the different types of rocks being categorised according to their capacity to maintain vegetation within the biogeographic units of Valencian coastal areas: Mediterranean region, West Mediterranean sub-region, ValencianProvençale-Balearic province, Valencian subprovince, Valencian-Tarraconense sector, Espadán Sierra and Castellonese district and dry ThermoMediterranean area (Rivas-Martinez et al. 2014; Costa Talens 1999).

Regarding human activity parameters, they are categorised according to the population and household density by census sections (INE 2008). We also take into consideration the road network structure (large infrastructures, roads, urban roads and historic rural roads) that guides and organises the territory, especially the large road and railway infrastructures, essential for the study, given that they fragment the territory and the landscape.

Once the necessary base information was collected, the patterns and landscape types were identified and the landscape units delimited, the information was homogenised by a digital adjustment for both aerial photography and historical cartographies. To this end, using Adobe Photoshop CS4 the photograms are aligned with grid tools and arbitrary rotation. Historical aerial photograms that do not have colour information are converted to 1 band, grayscale. All of them are adjusted for tone and contrast to improve the scanned image from analogical media, usually from positive print originals. The information of the flight and pass characteristics is trimmed to leave only the aerial image and the points of reference, by means of crop and canvas size tools provided by the software.

Prior to georeferencing, historical cartography was analysed using MapAnalyst software to evaluate its projection and positional accuracy. Spatial location of old maps was compared with a correctly processed current cartography (Jenny \& Hurni 2011). Georeferencing (Chias \& Abad 2009) was carried out with ArcGIS 10.3.1 in the projected coordinate system ETRS1989, UTM zone 30N using at least 4 control points that had a well identified correspondence with the current reference orthophoto. Control points were uniformly distributed over the full extent of the document to be georeferenced and were rectified using the most appropriate function. This function in the study area turned out to be projective transformation for aerial photography (years 1956 and 1977) and adjust transformation for planimetric maps (years 1910 and 1940). Orthophotography compositions corresponding to 1997 and 2015 were obtained from official entities, with geolocation criteria according to the Spanish Spatial Data Infrastructure (CNIG 2017).

\subsection{Landscape unit delimitation}

Landscape unit boundaries were delimited following a retrospective sequence, starting from the most recent time (2015) to the first date (1910), 
and characterised according to the established classification of landscape types in each time series studied. All the information is generated in a single vector file that includes all the time series. Together with the cartography, the data fields that unequivocally identify the unit and its type of landscape in the table of contents are added:

- Generation of a unique polygon name field, to identify it unequivocally. Initial polygon number, adding one letter per time series.

- Generation of landscape type field for each of the tabulated moments $(2015,1997,1977,1956$, 1940 and 1910). This will enable us to calculate the matrices of change between time series.

- Generation of surface and longitude (perimeter) fields, to perform statistical calculations of types and change over time, and to obtain the basic statistics associated with changing matrices and landscape patterns.

In each time series, all polygons were revised, subdivided, and assigned the landscape type at that historical state following an alphanumeric code that differentiates it from the others and has been maintained from its initial state to the end.

Once the landscape units have been obtained at each state, an analysis of their variation over time is carried out. First, a variability analysis is performed, using ArcGIS and the corresponding vector file, between each two contiguous states, to obtain the annual change rate. At the same time, taking advantage of the calculations made, we obtain the rate of change and the number of times a unit changes the landscape type over time series (Amici et al. 2017; Lang et al. 2008).

After performing the variability analysis, we proceed to perform a statistical analysis that shows the patterns of landscape change and its long-term trend (McGarigal et al. 2012). For this purpose, basic spatial metrics calculations are performed for each landscape type: number of patches (NP); sum, average and standard deviation of its surface; sum, average and standard deviation of its perimeter. In addition, fragmentation rates are calculated. For this research, we used the following landscape metrics, which were calculated to evaluate spatial-temporal trends: Largest Patch Index (LPI) in hectares; Patch
Density (PA) ratio of patches per hectare; Edge Density (ED) ratio of perimeter metres per hectare (Kumar et al. 2018; Amici et al. 2017; Jaeger 2000).

\section{Result and discussion}

\subsection{Landscape units, main features}

We identified seventeen types of landscape, of which 5 are urban and peri-urban, 6 agricultural, 3 forests and 3 water types (Table 2).

Table 2: Landscape types for areas of the western Mediterranean coastal strip.

\begin{tabular}{|c|c|c|}
\hline & Type & Urban and peri-urban landscape pattern \\
\hline U11 & Dense urban on lowlands & $\begin{array}{l}\text { Dense construction in land occupation } \\
\text { and building, alignment to public road, } \\
\text { on coastal and lowlands }\end{array}$ \\
\hline U12 & Scattered urban & $\begin{array}{l}\text { Scattered buildings with urban or } \\
\text { agricultural open spaces, on coastal, } \\
\text { lowlands and hills }\end{array}$ \\
\hline U13 & $\begin{array}{l}\text { Industrial and tertiary urban } \\
\text { on flat lands }\end{array}$ & $\begin{array}{l}\text { Buildings, facilities and endowments, on } \\
\text { coastal and lowlands }\end{array}$ \\
\hline U14 & $\begin{array}{l}\text { Urban free space on } \\
\text { lowlands }\end{array}$ & $\begin{array}{l}\text { Urban free space landscaped, on coastal } \\
\text { and lowlands }\end{array}$ \\
\hline U16 & Linear infrastructures & $\begin{array}{l}\text { Road and railway linear infrastructures } \\
\text { that fragment the landscape, on } \\
\text { lowlands }\end{array}$ \\
\hline
\end{tabular}

\begin{tabular}{|c|c|c|}
\hline & Type & Agricultural landscape pattern \\
\hline A21 & $\begin{array}{l}\text { Agricultural, orchard mosaic } \\
\text { irrigated on lowlands }\end{array}$ & $\begin{array}{l}\text { Agricultural mosaic of irrigated orchards, } \\
\text { on lowlands }\end{array}$ \\
\hline A22 & $\begin{array}{l}\text { Agricultural, irrigated citrus } \\
\text { fruits }\end{array}$ & Irrigated citrus fruits, on lowlands and hills \\
\hline A23 & $\begin{array}{l}\text { Agricultural, orchard mosaic } \\
\text { irrigated on marsh }\end{array}$ & $\begin{array}{l}\text { Agricultural mosaic of irrigated orchards, } \\
\text { on coastal wetland lands with drainage } \\
\text { channels }\end{array}$ \\
\hline A24 & $\begin{array}{l}\text { Agricultural, rice paddy on } \\
\text { marsh }\end{array}$ & $\begin{array}{l}\text { Rice paddy, on coastal wetland lands with } \\
\text { drainage channels }\end{array}$ \\
\hline A25 & Agricultural, pastures & $\begin{array}{l}\text { Pastures or land without apparent crops, } \\
\text { on coastal wetland lands and lowlands }\end{array}$ \\
\hline A26 & $\begin{array}{l}\text { Agricultural, rainfed } \\
\text { wooded mosaic }\end{array}$ & $\begin{array}{l}\text { Agricultural mosaic of carob trees, olive } \\
\text { trees, almond trees and rainfed vineyards, } \\
\text { on lowlands and hills }\end{array}$ \\
\hline & Type & Forest landscape pattern \\
\hline N31 & $\begin{array}{l}\text { Forested coniferous with } \\
\text { scrub on hillside }\end{array}$ & $\begin{array}{l}\text { Coniferous forest, understory and scrub } \\
\text { areas, on hills }\end{array}$ \\
\hline N32 & Garrigue, scrub on hillside & $\begin{array}{l}\text { Garrigue, understory and basophilic scrub, } \\
\text { on hills }\end{array}$ \\
\hline N33 & $\begin{array}{l}\text { Without vegetation on dry } \\
\text { riverbeds and beaches }\end{array}$ & $\begin{array}{l}\text { Land barren or with very little vegetation, } \\
\text { on dry riverbeds, beaches and hills }\end{array}$ \\
\hline
\end{tabular}




\begin{tabular}{lll}
\hline & Type & Water landscape pattern \\
\hline H41 & Marsh on wetland & $\begin{array}{l}\text { Marshes and lagoons, on a former coastal } \\
\text { lagoon }\end{array}$ \\
\hline H52 & Ma Cristina Reservoir & $\begin{array}{l}\text { Sheet of continental water generated by } \\
\text { the Ma Cristina reservoir }\end{array}$ \\
\hline H53 & Mediterranean Sea & Sheet of seawater, Mediterranean Sea \\
\hline
\end{tabular}

\subsection{Landscape units and dynamics}

The generated landscape units, characterised by their landscape type, allow their distribution to be represented with a homogeneous symbology for each time series. This affords a first visual approximation to models of association, changes and even fragmentation. Figure 3 compares the landscape types of the year 1910 with the types of the year 2015, appreciating the important landscape transformations between both states (location of typologies, area occupied by each type, big increase in landscape fragmentation, among others).

Changes in landscape types differ in amount and sign according to their typology (Table 3). Urban types increase their surface in every time series. Irrigated agricultural types are maintained over time, although changing their spatial position to be replaced by urban types, which in turn have replaced the rainfed types. The rainfed agriculture area has been reduced in every time series, but more sharply

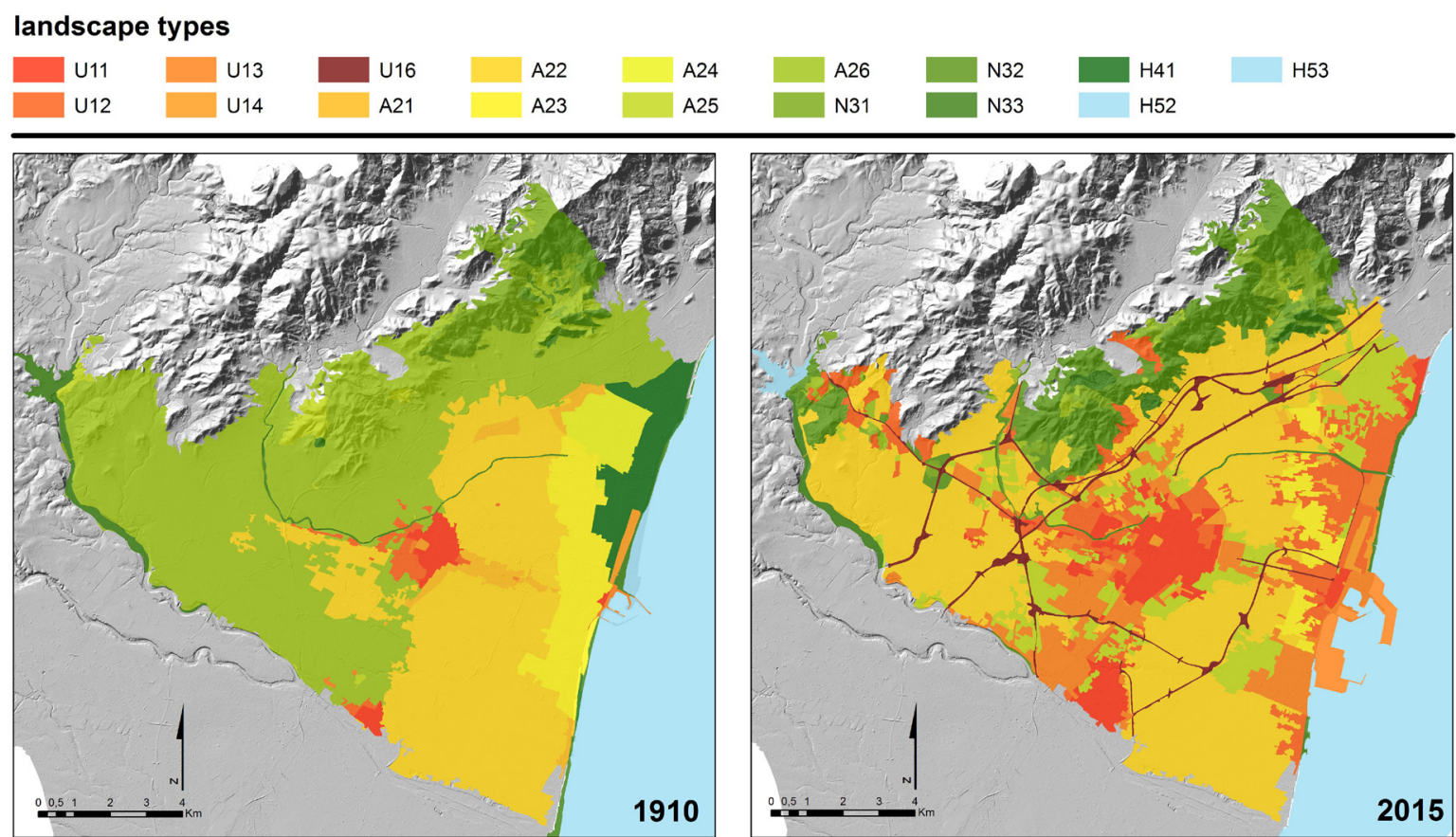

Figure 3: Map of changing landscape patterns. Study area, 1910-2015.

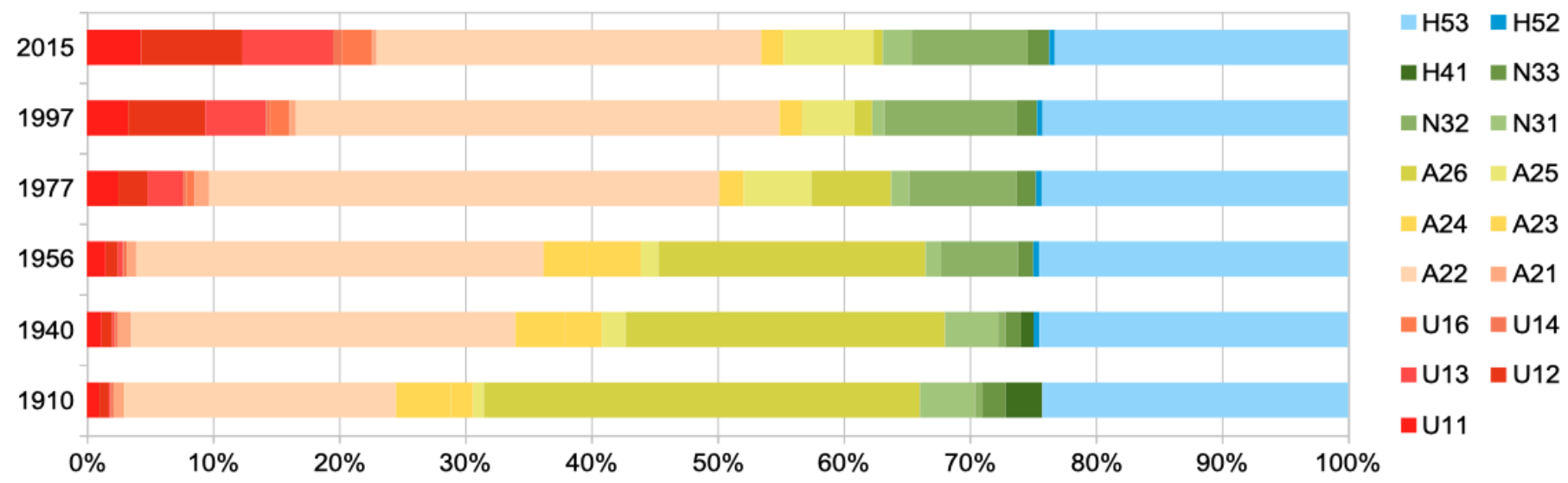

Figure 4: Variability chart of landscape types. 1910, 1940, 1956, 1977, 1997 and 2015. 
Table 3: Landscape types (\%) and rate change by type.

\begin{tabular}{|c|c|c|c|c|c|c|c|c|c|c|c|}
\hline Type & $\begin{array}{c}1910 \\
\%\end{array}$ & $\begin{array}{c}1940 \\
\%\end{array}$ & $\begin{array}{c}\text { Ratio } \\
1940 / 10\end{array}$ & $\begin{array}{c}1956 \\
\%\end{array}$ & $\begin{array}{c}\text { Ratio } \\
1956 / 40\end{array}$ & $\begin{array}{c}1977 \\
\%\end{array}$ & $\begin{array}{c}\text { Ratio } \\
1977 / 56\end{array}$ & $\begin{array}{c}1997 \\
\%\end{array}$ & $\begin{array}{c}\text { Ratio } \\
1997 / 77\end{array}$ & $\begin{array}{c}2015 \\
\%\end{array}$ & $\begin{array}{c}\text { Ratio } \\
2015 / 97\end{array}$ \\
\hline U11 & 0.98 & 1.17 & 1.2 & 1.49 & 1.3 & 2.50 & 1.7 & 3.28 & 1.3 & 4.29 & 1.3 \\
\hline U12 & 0.76 & 0.86 & 1.1 & 0.98 & 1.1 & 2.29 & 2.4 & 6.12 & 2.7 & 8.02 & 1.3 \\
\hline U13 & 0.14 & 0.17 & 1.3 & 0.38 & 2.2 & 2.84 & 7.4 & 4.81 & 1.7 & 7.21 & 1.5 \\
\hline U14 & 0.27 & 0.27 & 1.0 & 0.30 & 1.1 & 0.25 & 0.8 & 0.30 & 1.2 & 0.68 & 2.2 \\
\hline U16 & & & - & & - & 0.66 & - & 1.55 & 2.3 & 2.44 & 1.6 \\
\hline A21 & 0.80 & 1.03 & 1.3 & 0.75 & 0.7 & 1.13 & 1.5 & 0.49 & 0.4 & 0.34 & 0.7 \\
\hline A22 & 21.57 & 30.48 & 1.4 & 32.32 & 1.1 & 40.45 & 1.3 & 38.36 & 0.9 & 30.49 & 0.8 \\
\hline A23 & 4.34 & 3.96 & 0.9 & 3.39 & 0.9 & 1.95 & 0.6 & 1.80 & 0.9 & 1.80 & 1.0 \\
\hline A24 & 1.77 & 2.87 & 1.6 & 4.33 & 1.5 & & - & & - & & - \\
\hline A25 & 0.85 & 1.91 & 2.2 & 1.37 & 0.7 & 5.37 & 3.9 & 4.15 & 0.8 & 7.08 & 1.7 \\
\hline A26 & 34.57 & 25.32 & 0.7 & 21.18 & 0.8 & 6.32 & 0.3 & 1.40 & 0.2 & 0.75 & 0.5 \\
\hline N31 & 4.42 & 4.20 & 1.0 & 1.25 & 0.3 & 1.42 & 1.1 & 0.97 & 0.7 & 2.28 & 2.3 \\
\hline N32 & 0.57 & 0.58 & 1.0 & 6.07 & 10.5 & 8.54 & 1.4 & 10.50 & 1.2 & 9.25 & 0.9 \\
\hline N33 & 1.83 & 1.25 & 0.7 & 1.22 & 1.0 & 1.51 & 1.2 & 1.59 & 1.1 & 1.68 & 1.1 \\
\hline $\mathrm{H} 41$ & 2.90 & 0.99 & 0.3 & & - & & - & & - & & - \\
\hline H52 & & 0.46 & - & 0.46 & 1.0 & 0.46 & 1.0 & 0.46 & 1.0 & 0.46 & 1.0 \\
\hline H53 & 24.24 & 24.48 & 1.0 & 24.50 & 1.0 & 24.29 & 1.0 & 24.21 & 1.0 & 23.24 & 1.0 \\
\hline
\end{tabular}

since the middle of the twentieth century. Forest types have increased slightly over time series. Finally, water types have changed with the construction of the Maria Cristina reservoir and the disappearance of the marsh and rice paddy landscape (Figure 4).

Along with the quantified analysis of change rates, the variability of landscape types and the number of changes that have taken place over the last hundred years is also calculated (Figure 5). Most changes in landscape units occur only once, but there is also a significant number of units that have changed twice and a very low number that have changed three and even four times.

Besides the analysis of variability, we have also studied how changes affect the fragmentation of landscapes. To obtain the fragmentation in the study area, the number of patches (NP), the sum of the perimeter of the patches of each type (TE) and the density of the edges (ED) were calculated (Table 4). We can observe, from the evolution of the selected landscape metrics, that the fragmentation of the landscape units increases with time.

The fragmentation, illustrated in figure 6 , has grown from the outset in 1910 with 125 patches until its maximum in 1977 with 452 patches, an increase of $361 \%$. Since then, it has decreased to a lesser extent, reaching 358 patches in 2015, a reduction of $26 \%$. The greatest increases, both in the number of patches and in the length of its perimeter, have taken place in scattered urban (U12), urban industrial and tertiary (U13) landscape types, as well as in agricultural irrigated citrus fruit (A22) and agricultural pastures (A25) (Figure 6). 


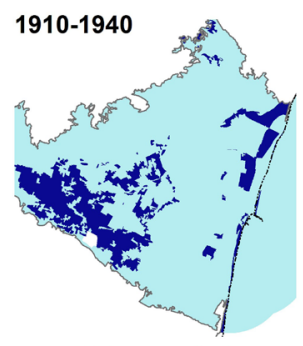

$0.44 \%$ annual change

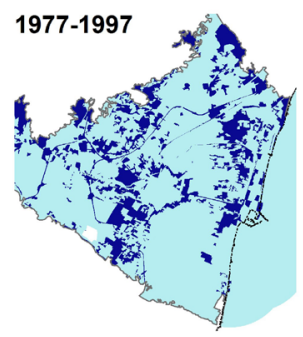

$0.86 \%$ annual change

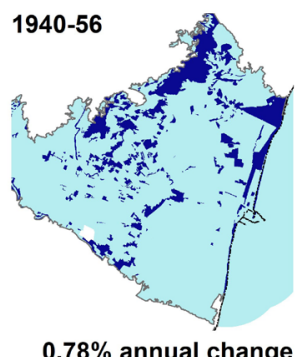

$0.78 \%$ annual change

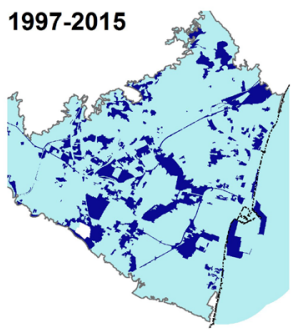

$0.83 \%$ annual change

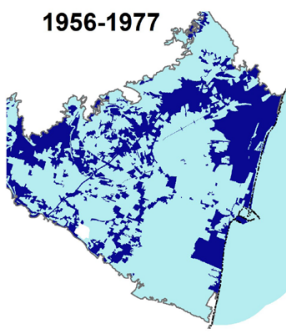

$1.24 \%$ annual change

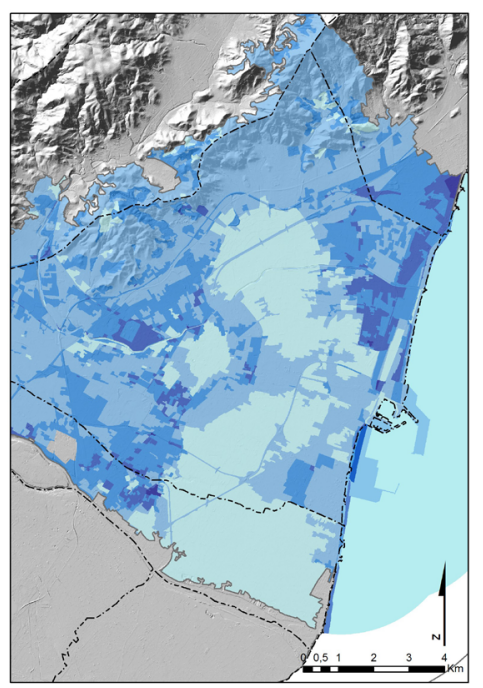

without changes $29.34 \%$ changes $70.66 \% \quad 1910-2015$

Figure 5: Variability map of landscape units. 1910 - 2015.

Table 4: Landscape metrics by type: number of patches (NP), total edge (TE) in kilometres and edge density (ED) ratio of metres per hectare.

\begin{tabular}{|c|c|c|c|c|c|c|c|c|c|c|c|c|c|c|c|c|c|c|}
\hline \multirow[t]{2}{*}{ Type } & \multicolumn{4}{|c|}{1910} & \multicolumn{3}{|l|}{1940} & \multicolumn{2}{|l|}{1956} & \multicolumn{3}{|c|}{1977} & \multicolumn{3}{|c|}{1997} & \multicolumn{3}{|c|}{2015} \\
\hline & NP & TE & ED I & NP & TE & ED & NP & TE & ED & NP & TE & ED & NP & TE & ED & NP & $\mathrm{TE}$ & ED \\
\hline U11 & 3 & 14.30 & 0.60 & 3 & 15.70 & 0.66 & 8 & 24.57 & 1.03 & 26 & 52.18 & 2.18 & 19 & 56.05 & 2.34 & 15 & 65.22 & 2.72 \\
\hline U12 & 13 & 26.10 & 1.09 & 17 & 31.88 & 1.33 & 35 & 46.39 & 1.94 & 82 & 115.81 & 4.83 & 81 & 236.57 & 9.87 & 66 & 240.38 & 10.03 \\
\hline U13 & 6 & 10.76 & 0.45 & 8 & 12.18 & 0.51 & 15 & 19.60 & 0.82 & 57 & 86.81 & 3.62 & 43 & 102.99 & 4.30 & 31 & 130.39 & 5.44 \\
\hline U14 & 2 & 6.05 & 0.25 & 2 & 6.05 & 0.25 & 3 & 6.31 & 0.26 & 3 & 5.71 & 0.24 & 5 & 8.03 & 0.34 & 14 & 27.25 & 1.14 \\
\hline U16 & 0 & - & - & 0 & - & & 0 & & & 4 & 47.57 & 1.98 & 8 & 115.50 & 4.82 & 1 & 172.71 & 7.21 \\
\hline A21 & 6 & 31.20 & 1.30 & 9 & 40.61 & 1.69 & 11 & 26.70 & 1.11 & 12 & 26.72 & 1.12 & 12 & 21.50 & 0.90 & 9 & 14.05 & 0.59 \\
\hline A22 & 14 & 114.99 & 4.80 & 292 & 214.74 & 8.96 & 26 & 241.09 & 10.06 & 32 & 327.35 & 13.66 & 55 & 360.01 & 15.02 & 70 & 341.78 & 14.26 \\
\hline A23 & 1 & 27.00 & 1.13 & 1 & 27.75 & 1.16 & 2 & 26.59 & 1.11 & 6 & 25.43 & 1.06 & 9 & 43.39 & 1.81 & 8 & 40.55 & 1.69 \\
\hline A24 & 2 & 10.91 & 0.46 & 3 & 18.63 & 0.78 & 2 & 22.73 & 0.95 & 0 & & & 0 & & & 0 & & \\
\hline A25 & 7 & 23.15 & 0.97 & 15 & 36.09 & 1.51 & 28 & 49.92 & 2.08 & 73 & 127.26 & 5.31 & 70 & 137.52 & 5.74 & 67 & 192.63 & 8.04 \\
\hline A26 & 23 & 211.67 & 8.83 & 602 & 289.57 & 12.08 & 69 & 342.13 & 14.27 & 83 & 201.00 & 8.39 & 40 & 64.22 & 2.68 & 25 & 33.84 & 1.41 \\
\hline N31 & 5 & 53.51 & 2.23 & 6 & 54.09 & 2.26 & 1 & 0.38 & 0.02 & 7 & 28.47 & 1.19 & 14 & 33.04 & 1.38 & 17 & 56.91 & 2.37 \\
\hline N32 & 16 & 36.63 & 1.53 & 10 & 34.40 & 1.44 & 45 & 167.99 & 7.01 & 46 & 202.12 & 8.43 & 28 & 173.70 & 7.25 & 21 & 155.76 & 6.50 \\
\hline N33 & 24 & 93.27 & 3.89 & 16 & 65.84 & 2.75 & 24 & 60.63 & 2.53 & 19 & 67.11 & 2.80 & 15 & 65.42 & 2.73 & 12 & 58.36 & 2.44 \\
\hline H41 & 2 & 24.37 & 1.02 & 2 & 18.45 & 0.77 & 0 & & & 0 & & & 0 & & & 0 & & \\
\hline H52 & 0 & - & - & 1 & 10.13 & 0.42 & 1 & 10.13 & 0.42 & 1 & 10.13 & 0.42 & 1 & 10.13 & 0.42 & 1 & 10.13 & 0.42 \\
\hline H53 & 1 & 52.10 & 2.17 & 1 & 52.01 & 2.17 & 1 & 52.87 & 2.21 & 1 & 53.15 & 2.22 & 1 & 53.96 & 2.25 & 1 & 60.10 & 2.51 \\
\hline ot & 125 & 7 & & 183 & 9 & & 271 & 3.02 & & 452 & 6.82 & & 401 & 82.01 & & 358 & 600.04 & \\
\hline
\end{tabular}




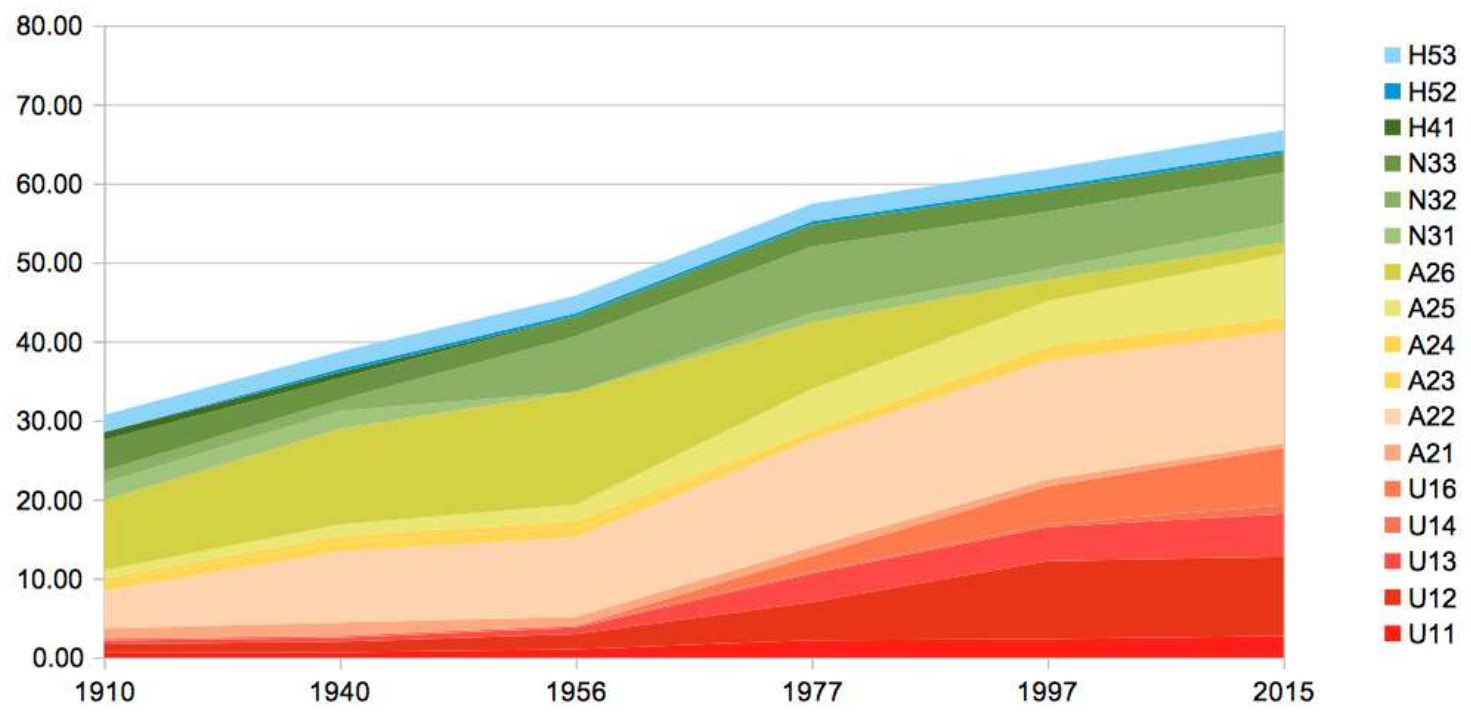

Figure 6: Landscape fragmentation by type: variability chart of edge density (ED) ratio of perimeter metres per hectare, 1910 to 2015.

\subsection{Discussion}

In the last years of the twentieth century, some of the landscape evolution studies carried out were characterised by their regional and supraregional geographical scope, type T0 and T1 of LTP (Gómez - Zotano et al. 2018), such as those elaborated by Plan Blue (Benoit et al. 2001) and the Mediterranean Commission on Sustainable Development (MCSD) (UNEP / MAP 2016). More recently, some analyses at smaller scales, subregional and supralocal, type T2 and T3 of LTP, have been carried out related to other sectors of the Mediterranean region, such as those focused on rural areas of the Spanish and Italian mountain regions (Agnoletti et al. 2015; Gómez Zotano et al.2018; Serrano, 2018; Statuto etal. 2016; Tortora et al. 2015). Regarding detailed studies in Spain, some works are related to landscape trends in coastal wetlands and agricultural surrounding environments, for example, the research focusing on the traditional farming area of Murcia (Mata \& Fernández 2004; (García - Martín \& Ros - Sempere 2016). The inland continental wetlands of the Iberian Peninsula have also been analysed (Vega-Pozuleo et al. 2017).

These works, however, do not incorporate the holistic study of the landscape as a cultural element in continuous transformation in space and time. This lack of integration and interaction in studies of urban, peri-urban, agricultural, forestry and water landscapes types makes it more difficult to analyse the dynamics of change over time and space. This study homogenises the characterisation of landscape types in order to analyse these models of change at local scale.

All the data gathered with this research will provide the basis to explore the possible future scenarios for the coming years. This will enable us to analyse the correlation between landscape types and the land classifications of current urban planning. In addition, the combination of future trends in landscape dynamics and their relationship with urban planning criteria may help establish the basis for the new future planning approaches.

\section{Conclusions}

The changes of the landscape in coastal spaces of the western Mediterranean coastal strip have taken place over space and time, due to the historical and intense human occupation of the coast, with a major increase over the last hundred years. In this period of time in the study area at local scale of TLP, landscape types that were predominant in previous centuries have disappeared, mainly the wetland marsh ( $\mathrm{H} 41)$ 
and the wooded mosaic on rainfed agricultural land (A26). These landscapes have been replaced mainly by urban and peri-urban types, both the dense (A11) and scattered (A22) on the lowlands and the industrial and tertiary (A13) ones more related to the new forms of land occupation by current societies. These transformations of the landscape have accelerated over the last hundred years and, to a greater extent, since the last quarter of the twentieth century. Furthermore, transformations have been aggravated by the fragmentation introduced by large infrastructures, landscape type of linear infrastructures (A16), which impede the connectivity and homogeneous visualisation of large areas of the territory. These data lead to the accumulation of the sum of the perimeter of the patches of each type (TE) and Edge Density index (ED), which have constantly increased throughout the study period.

This study generates the information and the base data with which to analyse the possible landscape scenarios in the coming years. For this purpose, Markov chain analysis and cellular automata will be performed. In addition, it will allow us to analyse the relationship between current urban planning strategies at each time series and their relationship with the landscape types generated. These historical landscape dynamics will facilitate better decisionmaking for future territorial and urban planning.

\section{References}

Agnoletti, M. 2014. Rural landscape, nature conservation and culture: Some notes on research trends and management approaches from a (southern) European perspective. Landscape and Urban Planning 126(0), 66-73. DOI: 10.1016/j. landurbplan.2014.02.012.

Agnoletti, M.; Conti, L.; Frezza, L. \& Santoro, A. 2015. Territorial Analysis of the Agricultural Terraced Landscapes of Tuscany (Italy): Preliminary Results. Sustainability 7(12), 4564-4581. DOI: 10.3390/ su7044564.
Aguilo Alonso, M.;Aramburu Maqua, M. P.; Blanco Andray, A.; Calatayud Prieto-Lavain, T. \& Carrasco González, R. M. 1992. Guía para la elaboración de estudios del medio físico. Ministerio de Obras Públicas y Transportes, Madrid.

Amici, V.; Maccherini, S.; Santi, E.; Torri, D.; Vergari, F. \& Del Monte, M. 2017. Long-term patterns of change in a vanishing cultural landscape: A GISbased assessment. Ecological Informatics 37(1), 38-51. DOI: 10.1016/j.ecoinf.2016.11.008.

Antrop, M. 1997. The concept of traditional landscapes as a base for landscape evaluation and planning. The example of Flanders Region. Landscape and Urban Planning 38(1), 105-117. DOI: 10.1016/S0169-2046(97)00027-3.

Antrop, M. 2000. Background concepts for integrated landscape analysis. Agriculture, Ecosystems \& Environment 77(1-2), 17-28. DOI: 10.1016/ S0167-8809(99)00089-4.

Antrop, M. 2005. Why landscapes of the past are important for the future. Landscape and Urban Planning 70(1-2), 21-34. DOI: 10.1016/j. landurbplan.2003.10.002.

Benevolo, L. 1994. La captura del infinito. Edited by M. García Galán. Celeste Ediciones, Madrid.

Benoit, G.; Coudert, E. \& Moriconi-Ebrard, F. 2001. Urbanisation in the Mediterranean Region from 1950 to 1995. http://planbleu.org/sites/default/ files/publications/cahier1_urbanisation_uk.pdf (Date: 21.02.2018).

Bürgi, M.; Silbernagel, J.; Wu, J. \& Kienast, F. 2015. Linking ecosystem services with landscape history. Landscape Ecology, 30(1), 11-20. DOI: 10.1007/s10980-014-0102-3

Carvalho-Ribeiro, S.; Ramos, I. L.; Madeira, L.; Barroso, F.; Menezes, H. \& Pinto Correia, T. 2013. Is land cover an important asset for addressing the subjective landscape dimensions? Land Use Policy 35, 50-60. DOI: 10.1016/j. landusepol.2013.04.015. 
Copernicus 2017. Copernicus, Land Monitoring Service, Pan European. http://land.copernicus. eu/pan-european (Date: 08.05.2017).

Costa Talens, M. 1999. La vegetación y el paisaje en las tierras valencianas. Madrid: Editorial Rueda.

Chias, P. \& Abad, T. 2009. Geolocating and Georeferencing: GIS Tools for Ancient Maps Visualisation. In 13th International Conference Information Visualisation. IEEE, 529-538. DOI: 10.1109/IV.2009.96.

CNIG 2017. National Geographic Information Centre. Downloads Centre CNIG. http:// centrodedescargas.cnig.es/CentroDescargas/ index.jsp (Date: 08.05.2017).

García Martín, F. M. \& Ros Sempere, M. 2016. Patterns of non-planned occupation of the peri-urban territory of the Huerta de Murcia, 1929-2015. In Back to the Sense of the City: International Monograph Book. Centre de Política de Sòl i Valoracions, 826-837. http://hdl.handle. net/2117/91017 (Date: 08.05.2017).

Gómez-Zotano, J.; Riesco-Chueca, P.; Frolova, M. \& Rodríguez-Rodríguez, J. 2018. The landscape taxonomicpyramid(LTP):amulti-scaleclassification adapted to spatial planning. Landscape Research, 1-16. DOI: 10.1080/01426397.2017.1404021

Institut cartogràfic valencià 2018. Cartografía del Instituto Cartográfico Valenciano, Infraestructura Valenciana de Dades Espacials. http://www.icv. gva.es/auto/aplicaciones/icv_geocat/ (Date: 15.02.2018).

Instituto Geológico y Minero de España 2017. Catálogo de Información Geocientífica del IGME Cartografía. http://info.igme.es/catalogo/default. aspx (Date: 08.05.2017).

INE 2008. Instituto Nacional de Estadística, INE base: operaciones estadísticas. http://www.ine.es/ inebmenu/indice.htm (Date: 08.05.2017).
Jaeger, J. A. G. 2000. Landscape division, splitting index, and effective mesh size: New measures of landscape fragmentation. Landscape Ecology 15, 115-130. DOI: 10.123/A:100812932989

Jenny, B. \& Hurni, L. 2011. Studying cartographic heritage: Analysis and visualization of geometric distortions. Computers \& Graphics. Elsevier 35(2), 402-411. DOI: 10.1016/j.cag.2011.01.005.

Kohler, F.; Marchand, G. \& Negrão, M. 2015. Local history and landscape dynamics: A comparative study in rural Brazil and rural France. Land Use Policy, 43, 149-160. DOI: 10.1016/j. landusepol.2014.11.010

Kumar, M.; Denis, D. M.; Singh, S. K.; Szabó, S. \& Suryavanshi, S. 2018. Landscape metrics for assessment of land cover change and fragmentation of a heterogeneous watershed. Remote Sensing Applications: Society and Environment 10, p. 224-233. DOI: 10.1016/j. rsase.2018.04.002.

Lang, S.; Walz, U.; Klug, H.; Blaschke, T. \& Syrbe, R.-U. 2008. Landscape metrics - A toolbox for assessing past, present and future landscape structures. In Krek, A. et al. (eds) Geoinformation Technologies for Geo-Cultural Landscapes. CRC Press; London. 207-234. DOI: 10.1201/9780203881613.ch10.

López Martínez, F.; Pérez Morales, A. \& Gil Guirado, S. 2016. In landscape management all of us have something to say. A holistic method for landscape Preservability evaluation in a Mediterranean region. Land Use Policy (51), 172-183. DOI: 10.1016/j.landusepol.2015.11.004.

Marcucci, D. J. 2000. Landscape history as a planning tool. Landscape and Urban Planning 49(1), 6781. DOI: 10.1016/S0169-2046(00)00054-2.

Mata Olmo, R. \& Fernández Muñoz, S. 2004. La Huerta de Murcia: landscape guidelines for a peri-urban territory. Landscape Research 29(4), 385-397. DOI: 10.1080/0142639042000289028. 
McGarigal, K. S.; Cushman, S.; Neel, M. \& Ene, E. 2012. FRAGSTATS: Spatial Pattern Analysis Program for Categorical and Continuous Maps [online] v.4. Amherst: University of Massachusetts. https:// www.researchgate.net/publication/259011515_ FRAGSTATS_Spatial_pattern_analysis_program_ for_categorical_maps (Date: 21.02.2018).

Obiol Menero, E. M. \& Soriano Martí, J. 2009.El sistema de riegos del Millars y los cambios en el paisaje de la huerta de la Plana. In Hermosilla Pla, J. (ed.) Los regadíos históricos del Baix Millars-La Plana: un patrimonio paisajístico en transformación. Confederación Hidrográfica del Jucar, Universitat de València Departament de Geografía; Valencia. 27-38.

Ode, Å.; Tveit, M. S. \& Fry. G. 2010. Advantages of using different data sources in assessment of landscape change and its effect on visual scale. Ecological Indicators 10(1), 24-31. DOI: 10.1016/j. ecolind.2009.02.013.

Palang, H.; Spek, T. \& Stenseke, M. 2011. Digging in the past: New conceptual models in landscape history and their relevance in peri-urban landscapes. Landscape and Urban Planning 100(4), 344-346. DOI: 10.1016/j.landurbplan.2011.01.012.

Plieninger, T.; Draux, H.; Fagerholm, N.; Bieling, C.; Bürgi, M.; Kizos, T. \& Verburg, P.H. 2016. The driving forces of landscape change in Europe: A systematic review of the evidence. Land Use Policy 57, 204-214. DOI: 10.1016/j. landusepol.2016.04.040.

Quereda Sala, J.; Montón Chiva, E. \& Escrig Barberá, J. 2010. Los recursos hídricos en el sistema hidrográfico del río Mijares- La Plana. Investigaciones Geográficas 51, 185-201. https:// dialnet.unirioja.es/descarga/articulo/3337342. pdf (Date: 08.05.2017).
Rivas-Martínez, S.; Penas, Á.; Díaz-Gonzáles, T. E.; Del Río, S.; Cantó, P.; Herrero, L. \& Costa, C. J. 2014. Biogeography of Spain and Portugal. Preliminary typological synopsis. International Journal of Geobotanical Research 4 (March), 1-64. DOI: 10.5616/ijgr140001.

Sanjaume Saumell, E. 1985. Las costas valencianas: sedimentología y morfología. Universidad de Valencia, Sección de Geografía, Valencia.

Segado Vázquez, F.; García Martín, A. \& Rosique Campoy, M. 1996. Ordenación del territorio. Universidad de Murcia, Murcia.https://books. google.es/books?id=2gx6A-IQbHOC (Date: 08.05.2017).

Serrano Giné, D. 2018. A Renewed Approach to the ABC Landscape Assessment Method: An Application to Muntanyes d'Ordal, Barcelona Metropolitan Area. Landscape Online 56, 1-18. DOI: 10.3097/LO.201856.

Smiraglia, D.; Ceccarelli, T.; Bajocco, S.; Perini, L, \& Salvati, L. 2015. Unraveling Landscape Complexity: Land Use/Land Cover Changes and Landscape Pattern Dynamics (1954-2008) in Contrasting Peri-Urban and Agro-Forest Regions of Northern Italy. Environmental Management, 56 (4), 916932. DOI:10.1007/s00267-015-0533-x

Statuto, D.; Cillis, G. \& Picuno, P. 2016. Analysis of the effects of agricultural land use change on rural environment and landscape through historical cartography and GIS tools. Journal of Agricultural Engineering 47 (1), 28. DOI: 10.4081/ jae.2016.468.

Stephenson, J. 2008. The Cultural Values Model: An integrated approach to values in landscapes. Landscape and Urban Planning, 84(2), 127-139. DOI: 10.1016/j.urbanplan.2007.07.003 
Tieskens, K. F.; Schulp, C. J. E.; Levers, C.; Lieskovský, J.; Kuemmerle, T.; Plieninger, T, \& Verburg, P.H. 2017. Characterizing European cultural landscapes: Accounting for structure, management intensity and value of agricultural and forest landscapes. Land Use Policy. Pergamon 62, 29-39. DOI: 10.1016/j.landusepol.2016.12.001.

Tortora, A.; Statuto, D. \& Picuno, P. 2015. Rural landscape planning through spatial modelling and image processing of historical maps. Land Use Policy. Elsevier 42, 71-82. DOI: 10.1016/j. landusepol.2014.06.027.

UNEP/MAP 2016 Mediterranean Strategy for Sustainable Development 2016-2025. Valbonne. https://planbleu.org/sites/default/files/ publications/mssd_2016-2025_final.pdf (Date: 21.02.2018).

Vega-Pozuleo, R.; Torres-Márquez, M. \& NaranjoRamírez, J. 2017. Recursos cartográficos y geohistóricos para el inventario de humedales temporales y desecados mediterráneos. GeoFocus 19, 151-179. DOI: 10.21138/GF.407.

Velázquez, A. \& Bocco, G. 2001. Land unit approach for biodiversity mapping. In Zee, D. van der \& Zonneveld, I. S. (eds) Landscape ecology applied in land evaluation, development and conservation: some worldwide selected examples. ITC Public. Enschede: ITC, 273-285. http://dunza.com.mx/ zacatuche/PDF/613Capitulos en Libros/6132Inte rnacionales/6132-5.pdf (Date: 08.05.2017).

Wascher, D.M. (ed). 2005. European Landscape Character Areas - Typologies, Cartography and Indicators for the Assessment of Sustainable Landscapes. Final Project Report as deliverable from the EU's Accompanying Measure project European Landscape Character Assessment Initiative (ELCAI), funded under the 5th Framework Programme on Energy, Environment and Sustainable Development. http://library. wur.nl/WebQuery/wurpubs/fulltext/1778 (Date: 21.02.2018).
Zonneveld, I. S. 1989. The land unit? A fundamental concept in landscape ecology, and its applications. Landscape Ecology 3(2), 67-86. DOI: 10.1007/ BF00131171. 